\title{
Contextual Learning Method, Learning Facility and Motivation in Relation to Sociology Learning Outcome
}

\author{
Johanna Albertina Latuny \\ SMA Negeri 2 Ambon Maluku \\ Ambon, Indonesia \\ johanna_al@gmail.com
}

\author{
Lilik Sri Hariani \\ Master of Social Science Education Study Program \\ Universitas PGRI Kanjuruhan Malang \\ Malang, Indonesia \\ liliksrihariani@unikama.ac.id
}

\author{
Lasim Muzammil* \\ Master of English Education Study Program \\ Universitas PGRI Kanjuruhan Malang \\ Malang, Indonesia \\ *muzammil_lasim@unikama.ac.id
}

\begin{abstract}
This study was aimed at examining the simultaneous effect of contextual learning methods, learning facilities, and motivation on the students' learning outcome. A survey as a part of the quantitative research design was employed by utilizing 139 samples out of 210 population. To collect data, a questionnaire was distributed to the samples getting involved in the present study, and to ascertain that the instrument was valid and reliable, Pearson Product Moment and Cronbach Alpha were used to test this instrument. Data were stored in SPSS and analyzed using Multiple Regression Analysis after conducting some sets of testing including classical assumption test, normality test, collinearity, heteroskedasticity, and homoscedasticity test as a prerequisite on using multiple regression analysis. It was found that there was a significant correlation among the contextual learning method, learning facility, and motivation on the students' learning achievement of sociology subject matter. The more often contextual learning was used, the more complete facility the school has, and the more motivated students have tended to have better learning achievement on sociology. Therefore, teachers, practitioners, and syllabus designers ought to pay close attention to the learning method, learning facility, and motivation to develop the students' sociology achievement.
\end{abstract}

Keywords - contextual learning methods, learning facilities, motivation, students' learning outcome

\section{INTRODUCTION}

Every activity in education will occur in the learning process. Learning occurs because there is an interaction or reciprocal relationship between students and teachers as educators. In every learning process, of course, an educator has learning objectives that must be achieved by students so that the learning process runs well. Therefore, to achieve the goals or objectives of the learning process, an educator must prepare himself, including planning the lesson well and interestingly. According to Aritonang [1], "Learning is a process of the effort carried out by individuals to obtain new behavioral changes as an individual's own experience." So that through his learning experience, a student will experience changes in his behavior.

One aspect that also influences learning activities to achieve its goals is the selection of learning methods or methods that are appropriate and by the conditions of students. The Contextual Teaching Learning method is a learning approach that can influence the learning process, especially for social studies learning because students will be invited and encouraged to connect classroom learning with real-life contexts that occur in community life. The learning process with this approach will take place naturally because the students themselves work and are directly involved. Contextual Teaching Learning is a learning concept in which the teacher presents the real world into the classroom. He encourages students to make connections between their knowledge and their application in everyday life. Besides, students acquire knowledge and skills in a limited context little by little, and from the process of reconstructing themselves, as a provision in solving problems in life as a member of society [2]. Therefore, the contextual learning approach has a positive influence on students in the learning process, especially social studies learning. Besides, a learning process will be more effective and efficient by the supports of adequate learning facilities for students. Studying facilities are supporting facilities and infrastructure that bridge the smoothness of the learning process to achieve its goals. 
According to Dimyati and Mudjiono [3], "learning facilities are facilities and infrastructure owned by schools that support directly and indirectly in the learning process, for that student learning facility are expected to be adequate and by standards in schools in general." Likewise, as stated in Law No. 20 of 2013 article 45 paragraph 1 concerning educational facilities that: "Every education unit, both formal and non-formal, provides facilities that meet educational needs by the growth and development of physical potential, intellectual, social, emotional intelligence, and the obligations of students." Thus, each school is obliged to provide both learning facilities and infrastructure that will help facilitate and streamline the teaching and learning process in schools because they are crucial factors that can influence on improving student learning outcomes.

Every learning process that occurs, especially in the classroom, really requires full concentration on the learning motivation of individual learners. It is because encouragement is an emotional form that encourages to be able to spur enthusiasm and persistence in a learning process. Usually, a student's motivation can see when there is a concentration of students that continues with the active response of students to learning activities. In other words, the factor that influences the interaction of learning activities in class is the motivation of students.

According to Mardianto [4] motivation is defined as a process that gives encouragement, direction, and behavior persistence. Mardianto provides three keywords from the understanding of psychology, namely an impetus to take action, a consideration to prioritize alternative action, and an environment that provides or becomes a source of input or argument for someone to take the first or second action. From some of the definitions of motivation above, it concluded that encouragement is a conscious or unconscious urge to take any action or not.

Based on the statements of the problems, the researcher states the following objectives:

- Analyze the simultaneous effect of contextual learning methods, facilities, and learning motivation on the students' sociology learning outcomes of Grade X SMA Negeri 2 Ambon;

- Analyze the influence of the contextual learning approach on the students' sociology learning outcomes of Grade X students of SMA Negeri 2 Ambon;

- Analyze the effect of learning facilities on the students sociology learning outcomes of Grade X SMA Negeri 2 Ambon; and

- Analyze the influence of learning motivation on the students' sociology learning outcomes of Grade X students of SMA Negeri 2 Ambon.

Theoretically, the results of this research will provide the development of knowledge, particularly in the world of education and learning. This study is also a foundation and learning resource for other writers in their research related to contextual learning methods with facilities and learning motivation for student learning outcomes. Practically, it is as input material for sociology subject teachers to play a role in increasing student learning motivation to achieve maximum learning outcomes. So, the students have strong encouragement through contextual learning methods and adequate facilities to achieve maximum learning outcomes and for a brighter future. Besides, schools can develop learning models or learning approaches that are more innovative so that they can create quality students.

Many previous researchers have conducted studies on the same topic as this research. First, a study was conducted by Sholeh and Sa'diah [5] concerning the Effect of Learning Motivation and Learning Facilities on Social Studies Learning Achievement of Nurul Iman Parung Bogor Middle School Students in the 2017/2018 Academic Year. The study revealed that students who have high motivation and adequate facilities have an impact on high learning outcomes. On the other hand, Bakar [6] conducted a study entitled The Effect of Learning Motivation on Students' Productive Competencies in Vocational High Schools, West Sumatra, resulted that learning both from within and from outside individual students through appropriate and learning methods made students are interested and like the teacher's learning.

Furthermore, Riyani and Palupiningdyah [7] conducted a study on the influence of motivation variables and learning facilities on student learning outcomes in the VIII class of Social Science subjects in SMP Negeri 1 Karangreja Purbalingga. It revealed that the higher the motivation and the better the facilities make student learning outcomes increase. Likewise, Surdin [8] conducted research entitled The Effect of Contextual Teaching and Learning (CTL) Models on Learning Outcomes of Social Science of the Material of Forms The Face of The Earth on Class VII of Junior High School. The results of his research stated that by using contextual learning, there is an increase in student learning outcomes where $78 \%$ of student learning outcomes have increased. Also, Neftyanet al. [9] conducted research entitled The Influence of Learning Using Contextual Teaching and Learning Approach to Physics Learning Outcomes of High School Students. The results of his study prove that by using a contextual learning approach, there is an increase in student learning outcomes.

Taurina [10] has also conducted similar research entitle Students' Motivation and Learning Outcomes: Significant Factors in the Internal Study Quality Assurance System. The results of his study revealed that motivation is a very significant factor in determining student achievement and learning outcomes. It focused on the elements of encouragement influenced by the learning environment, students themselves, and teachers. Lee et al. [11] carried out a study on the Acceptance of Internet-Based Learning Medium: The Role of Extrinsic and Intrinsic Motivation. The results of this study indicated that the use of internet media is beneficial to encourage the students' motivation both from outside and from within students, and it has an impact on the achievement 
of student learning outcomes. Likewise, a study conducted by Jeffrey and Zein [12] entitled The Effects Of Achievement Motivation, Learning Discipline and Learning Facilities On Student Learning Outcomes showed that facilities are variables that affect much the level of thinking skills and academic potential of students. It encourages increasing learning motivation and influencing student learning outcomes. Similarly, a study conducted by Asvio [13] on The Influence of Learning Motivation and Learning Environment on Undergraduate Students' Learning Achievement of Management of Islamic Education, stating that learning motivation has a positive influence and significant impact on the achievement of better student learning outcomes as well.

Meanwhile, a study conducted by Ilomo and Mlavi [14] entitles The Availability of Teaching Learning Facilities and Their Effects on Academic Performance in Ward Secondary Schools in Muheza-Tanzania revealed the lack of facilities or infrastructure. Consequently, it resulted in a lack of students' motivation in which finally leads to a lack of achievement of student learning outcomes. Similar research was also conducted by Bijaya [15] regarding the Relationship Among School's Infrastructure Facilities, Learning Environment, and Student's Outcomes, with the results of his research indicating that $70 \%$ of the conditions of school infrastructure affect student learning outcomes. It means that students' achievement in learning is directly affected by the status of school infrastructure facilities. Similarly, Limon [16] carried out the research, namely The Effect of the Adequacy of School Facilities on Student's Performance and Achievement in Technology and Livelihood Education, that provides evidence that a lack of learning facilities in schools have an impact on decreasing student learning outcomes.

The hypothesis of this research is (1) there is a simultaneous effect of the application of a contextual learning approach with facilities and learning motivation on learning outcomes of Sociology Social Studies students of SMA Negeri 2 Ambon. (2) there is an effect of the application of a learning approach to the social studies learning outcomes of Sociology students of SMA Negeri 2 Ambon. (3) There is an effect of the effect of facilities on the social studies learning outcomes of Sociology students of SMA Negeri 2 Ambon. (4) There is an effect of learning motivation on social studies learning outcomes of Sociology students of SMA Negeri 2 Ambon.

\section{METHODS}

The approach used in this study is a correlational approach, namely the researcher will look for correlations that influence independent variables on the dependent variable. To calculate the results of data collection and analysis, we used statistical formulas of the value of each variable. The population of this research is 210 students of class X IPS major in SMA Negeri 2 Ambon with a sample of 139 students.

Data collection techniques in this study using a questionnaire or questionnaire method and documentation. A researcher used a questionnaire to collect data about the application of the effect of the contextual learning method (X1) with facilities (X2) and interest in learning (X3). Meanwhile, the data needed as documentation is a list of student scores in the 2018-2019 academic year, student data, and other data to analyze research data. The intended research data are those related to student learning outcomes (variable Y). The researcher tested the research instrument using a validity test. The rule used is that it is said to be valid if $r$ value $>r$ table with a significance level of $5 \%$ and if $r$ value $<r$ table, then the question is declared invalid. To test the level of reliability, we used Cronbach Alpha.

Instrument reliability test used alpha value. A questionnaire is said to be reliable if a respondent's answer to a question is consistent or stable over time. We stated that a variable is reliable if the value of Cronbach Alpha $(a)>0.60$. Thus, if the Cronbach Alpha (a) value $>0.60$, the tested questionnaire will prove to be reliable. The research instrument intended is a measurement of the variables to be researched and tested. Testing this instrument was carried out on 30 students using a Likert scale. This Likert scale instrument is useful if the researcher measures the whole instrument. The answer to each instrument item using a Likert scale has a level from very positive to very negative. Guidelines for the assessment of each item, we formulated in words scales as seen in Table 1.

TABLE I. THE SCORE OF LiKERT SCALE AsSESSMENT ON QUESTIONNAIRE

\begin{tabular}{|c|l|c|}
\hline Code & \multicolumn{1}{|c|}{ Description } & Score \\
\hline SA & $\begin{array}{l}\text { Stongly Agree, meaning almost always and very } \\
\text { often experience or feel }\end{array}$ & 5 \\
\hline A & $\begin{array}{l}\text { Agree, meaning that they tend to experience or } \\
\text { feel frequently }\end{array}$ & 4 \\
\hline N & $\begin{array}{l}\text { Neutral, meaning tends to experience or feel } \\
\text { occasionally }\end{array}$ & 2 \\
\hline D & Disagree, meaning that you tend not to do & 1 \\
\hline SD & $\begin{array}{l}\text { Strongly Disagree, meaning absolutely never do } \\
\text { or feel }\end{array}$ & \\
\hline
\end{tabular}

The data analysis technique used multiple linear regression analysis. We used this technique because the independent variable was more than one effect, or it has several independent variables imposed on the dependent variable. It aims to determine the influence of the independent variables, namely, the contextual learning methods with learning facilities and sociology motivation) on the dependent variable (learning outcomes). The hypothesis testing on the effect of the contextual learning method with learning facilities and motivation, multiple regression analysis used the criteria $F$ valued > F table. The SPSS computer program helped the implementation of this hypothesis testing.

The analysis technique used in this research is a linear regression technique that aims to determine the effect of a variable on other variables. Likewise, the data analysis technique in this study was carried out partially by looking at the effect of each independent variable on the dependent variable with the regression equation, while the simultaneous 
analysis aims to see all independent variables on variables related to regression search with the help of SPSS.

The data analysis in this study went through several stages, including the preparation stage and the classical assumption test. The assumption test phase includes the normality test, linearity test, and multicollinearity test with the SPSS 20 computer program. Research Hypothesis Testing Phase, we used Multi-Regression. At this stage, the researcher will use multi-regression with the intention of reacting to the independent variable against the dependent variable. This hypothesis test uses the Simultaneous Test ( $F$-test), Partial Test ( $t$-test), and Simultaneous Determination Coefficient (R2).

\section{RESULTS AND DISCUSSION}

The results of the research and the discussion in this study were the reviews of using the descriptive stage of research data and research results. The research problem variables adjusted the reporting of research results and described the research variables. The variables used are three independent variables and one dependent variable. The independent variable is about the influence of contextual learning methods (X1), facilities (X2), and learning motivation (X3), meanwhile the dependent variable is the learning outcomes of students of SMA Negeri 2 Ambon (Y). We presented the research data consecutively by starting from the dependent variable, then proceeding with other independent variables.

The process of validating the score is using a computer to avoid mistakes in calculating the score so that the research can be scientifically justified. The validity of this research data used the calculation within the correlation technique of Pearson Product Moment. It shows the item correlation coefficient ( $r$-valued) for the instrument (questionnaire) with a sample of 30 people $(n=30)$, with $\alpha=0.05$, the $r$ table is 0.349. It means that if $r$ valued $>\mathrm{r}$ table, then the instrument item is invalid, and if $r$ valued $>r$ table, then the instrument item can be used (valid). From the statistical calculations for each variable, it turns out that the calculated $r$ obtained is greater than the $r$ table, so it concluded that all questionnaire items were valid in prediction. Meanwhile, for the questionnaire, contextual learning method, the researchers used 30 students as respondents who were not the research sample.

The results of the reliability test showed that the reliability value (Cronbach Alpha) for each variable was 0.930 . If you get a high coefficient value of 0.9 and above, the level of trust is very high. It concluded that the measuring instrument in the study is reliable. Based on the results of the validity test, we see that the correlation coefficient for the instrument validity test of the contextual learning method (X1) obtained $r$ valued $>r$ table in which $r$ table was from the Table of Pearson Product Moment value. The degrees of freedom $(d f)=\mathrm{N}-2, \mathrm{~N}$ is the number of respondents. The significance (error level) used is $5 \%$, and the value of $r$ table $=0.349$ is obtained. Therefore, from the calculated data performed above, it can be stated that all items are valid.
In the Facility questionnaire, researchers used 30 students as respondents who were not the research sample. The reliability value (Cronbach Alpha) for each variable is 0.960 . If you get a high coefficient value of 0.9 and above, the confidence is very high, so the measuring instrument in the study is reliable. Based on the results of the validity test, the value of the correlation coefficient for the validity test of the facility variable instrument (X2) with the criteria for interpreting the validity, the calculation obtained is $r$ valued $>r$ table, with degrees of freedom $(d f)=\mathrm{N}-2 . \mathrm{N}$ is the number of respondents, and the significance (level of error) used is $5 \%$, the value of $r$ table obtained $=0.349$. Based on the calculated data above, all items are valid.

In the study motivation questionnaire, researchers used 30 students as respondents who were not the research sample. The results of the reliability test (Cronbach Alpha) for each variable were 0.938 . If you get a high coefficient value of 0.9 and above, the level of trust is very high, then the measuring instrument in the study is reliable. Based on the results of the validity test, the value of the correlation coefficient for the validity test of the learning motivation variable instrument (X3) is $r$ valued $>r$ table. The Pearson Product Moment value with degrees of freedom $(d f)=\mathrm{N}-2$ where $\mathrm{N}$ is the number of respondents, and the significance (level of error) used is $5 \%$, and the value of $r$ table $=0.349$. Therefore, all items were declared valid.

In the questionnaire of student learning outcomes styles, researchers used 30 students as respondents who were not the research sample. The results of the reliability test (Cronbach Alpha) for each variable were 0.916. If you get a high coefficient value of 0.9 and above, the trust is very high, so the measuring instrument in the study is said to be reliable. Based on the results of the validity test, the value of the correlation coefficient for the validity test of the instrument variable learning motivation (Y) with the criteria for interpreting the validity of the instrument after the calculation is obtained is $\mathrm{r}$ valued $>r$ table, $r$ table with degrees of freedom $(d f)=\mathrm{N}-2$, where $\mathrm{N}$ is the number respondents and the significance (level of error) used is 5\%, so that the value of $r$ table $=0.349$. Based on the calculated data, it can be stated that all items are valid.

\section{A. Research Data Testing}

The testing of research data used the classical assumption test and multiple regression tests that includes testing the normality of the data. We carried out this test in two ways, namely, a histogram made for the standardized residual distribution, and a normality probability plot made for each model. To obtain accurate results, the researchers carried out the calculations with the help of the SPSS computer program. From the resulting histogram output, it appears that each data spreads throughout the normal area. It is the area under the curve that looks like a bell-shaped. From the image of the PPlot Normality test in Figures $\mathrm{X}$ and $\mathrm{Y}$, the points spread around the line and follow the diagonal line, so we concluded that the regression model is a normal distribution. 
The researchers used a collinearity test to determine the collinearity among the independent variables. The method used is to calculate tolerance and VIF to obtain the Tolerance value and VIF value for each of the research stages. From the output, the VIF value is less than 10 points, and a tolerance value is more than 0.1 for the two variables. The researchers concluded that the regression model does not have a multicollinearity problem. We used the heteroscedastic test to check whether the distribution of $\mathrm{Y}$ data is random for each value of variable $\mathrm{X}$. For this test, the researcher uses a Scatterplot Diagram between predicted and residual values. The result is that the data is scattered around the number 0 ( 0 on the Y-axis) and does not form a particular pattern or trend line. Thus, the data can be said to be homoscedastic and meet the requirements for regression analysis.

From the results of calculations with the help of SPSS, the effect of contextual learning methods (X1), facilities (X2), and learning motivation (X3) on student learning outcomes (Y), the Durbin Watson statistic value is .927 , then 4 - $\mathrm{dl}=2,7563$ and 4-du $=2.3495$ so that $2.3495<\mathrm{DW} .927$ Ho is accepted. So, we cannot find autocorrelation, or there is no autocorrelation in the regression model.

\section{B. Hypothesis Testing}

Hypothesis 1 states that "it is suspected that there is a significant simultaneous effect between contextual learning methods, facilities and learning motivation on student learning outcomes". From the output of the analysis, it can be seen that the value of multiple linear regression analysis means that the equation is: $\mathrm{Y}=\mathrm{a}+\mathrm{b} 1 \mathrm{X} 1+\mathrm{b} 2 \mathrm{X} 2+\mathrm{b} 3 \mathrm{X} 3$. $\mathrm{Y}=16,866+.503$ $\mathrm{X} 1+132 \mathrm{X} 2+.308 \mathrm{X} 3$. (Note: $\mathrm{Y}=$ dependent variable $\mathrm{X} 1 \mathrm{X} 2 \mathrm{X} 3=$ independent variable. $\mathrm{A}=$ constant value. $\mathrm{B} 1 \mathrm{~b} 2 \mathrm{~b} 3$ $=$ regression coefficient

The constant value is 16.866 indicates that if the contextual learning approach, facilities, and learning motivation are 0 , then the student learning outcomes are 16.866. The regression coefficient of the contextual learning approach variable is 0.503 , meaning that if the training has increased by one unit, the student learning outcomes have increased by 0.503 units under the assumption that other independent variables are fixed. The facility variable regression coefficient is 0.132 , meaning that if the facility has increased by one unit, then student's learning outcomes will increase by 0.132 units with the assumption that other independent variables are of a fixed value. The regression coefficient of the learning motivation variable is 0.308 , meaning that if the learning motivation increases by one unit, then student learning outcomes will increase by 0.308 units, assuming other independent variables are of a fixed value.

Determination analysis is used to determine the percentage of the contribution of the simultaneous effect of the independent variables on the dependent variable. The results of the determination analysis can be seen in the Model output summary of the results of multiple linear regression analysis.
Hypothesis 2 states "it is suspected that there is a significant effect of the contextual learning approach on student learning outcomes". From the output of the analysis, it is known that the simple regression correlation value is obtained, the equation: $Y$ $=\mathrm{a}+\mathrm{bx}=16.866+0.503 \mathrm{X}$. With $\mathrm{Y}=$ the dependent variable $\mathrm{X}=$ independent variable, $\mathrm{a}=$ constant value, and $\mathrm{b}=$ regression coefficient.

It was obtained a constant value of 16.866 , meaning that if the contextual learning method is 0 , then the value of student learning outcomes is 16.866 . The regression coefficient of the contextual learning method variable is 0.503 , meaning that if the contextual learning method has increased by one unit, the student learning outcomes will increase by 0.503 units. The coefficient is positive, meaning that the relationship between contextual learning methods and performance is positive, meaning that the higher the training, the higher the performance. The Adjusted R Square coefficient is 0.935 , so it can be concluded we reject the null hypothesis. It proves that the contextual learning method has the effect of the Adjusted R Square of 0.93.5 from the student learning outcomes with a sig. value amounting to 0.000

Hypothesis 3 states, "it is suspected that there is a significant effect of facilities on student learning outcomes." From the results of the analysis, it is known that the simple regression correlation value is obtained by the equation: $\mathrm{Y}=\mathrm{a}$ $+\mathrm{bX}=16.866+0.132 \mathrm{X}$. With $\mathrm{Y}=$ dependent variable, $\mathrm{X}=$ independent variable, $\mathrm{a}=$ constant value, $\mathrm{b}=$ regression coefficient.

It is obtained a constant value of 16.866 , meaning that if the facility is 0 , then the student's learning outcomes are 16.866 . The facility variable regression coefficient is 0.132 , meaning that if the facility has increased by one unit, then student's learning outcomes have increased by 0.132 units. The coefficient is positive, meaning that the relationship between facilities and student's learning outcomes is positive, meaning that the higher the facilities, the higher the student learning outcomes. The Adjusted R Square coefficient is 0.935, indicating that we reject the null hypothesis. It proves that the facility has a share of the Adjusted R Square of $93.5 \%$ of student's learning outcomes; indicated by the performance with the value of sig. is 0.000 .

Hypothesis 4 states, "it is suspected that there is a significant influence of learning motivation on the learning outcomes of class X SMA Negeri 2 Ambon". From the results of the analysis, the simple regression correlation value with the equation: $\mathrm{Y}=\mathrm{a}+\mathrm{Bx}=16.866+308 \mathrm{x}$. With $=\mathrm{Y}=$ dependent variable, $\mathrm{X}=$ independent variable, $\mathrm{a}=$ constant value, $\mathrm{b}=$ regression coefficient. Obtained a constant value of 16.866 , meaning that student's learning outcomes are 0 , then the learning motivation is 16.866 . The regression coefficient of the learning motivation variable is 0.308. The coefficient is positive, meaning that the relationship between the profitability ratio and audit delay is positive. It means that the higher the profitability ratio, the higher the audit delays. The Adjusted $\mathrm{R}$ Square coefficient is 0.935 , so we reject the null hypothesis. It 
proves that learning motivation has contributed to the Adjusted $\mathrm{R}$ Square of $93.5 \%$ of learning motivation indicated by the learning outcomes of these students with a sig. value amounting to 0,000 .

\section{Discussion}

1) A significant effect among contextual learning methods, facilities and learning motivation on student learning outcomes: The results of the calculation show that the sociology learning outcomes of class X SMA Negeri 2 Ambon can be affected by the simultaneous effects of contextual learning methods, facilities, and learning motivation. We stated the results of the F-value $651.784>$ F-table 2.947. The regression equation is shown by the equation $\breve{\mathrm{y}}=16.866+$ $0.503 \mathrm{X} 1+0.132 \mathrm{X} 2+0.308 \mathrm{X} 3$. These findings indicate that there is a positive and significant effect of $93.5 \%$ of the contextual learning method, facilities, and learning motivation together on the learning outcomes of class X students of SMA Negeri 2 Ambon. Meanwhile, the remaining 6.5\% is affected by other variables not examined in this study (See Table 2 as follows).

TABLE II. F TEST RESULTS FOR EACH VARIABLE

\begin{tabular}{|c|l|c|c|c|c|c|}
\hline \multicolumn{7}{|c|}{ ANOVA $^{\mathbf{b}}$} \\
\hline \multirow{2}{*}{\begin{tabular}{c} 
Model \\
\multirow{2}{*}{1}
\end{tabular}} & $\begin{array}{c}\text { Sum of } \\
\text { Squares }\end{array}$ & Df & Mean Square & F & Sig. \\
\cline { 2 - 7 } & Regression & 3286.925 & 3 & 1095.642 & 651.784 & $.000^{\mathrm{a}}$ \\
\cline { 2 - 7 } & Residual & 223.572 & 133 & 1.681 & & \\
\cline { 2 - 7 } & Total & 3510.496 & 136 & & & \\
\hline
\end{tabular}

a. Predictors: (Constant), Motivation, Facility, Contextual learning

${ }^{\text {b. }}$ Dependent Variable: Learning outcome

This study confirms that student's learning outcomes are optimal by combining motivation, facilities, and contextual learning simultaneously. This research is in line with Hamdayama [2] stating that contextual learning approach has a positive influence on students in the learning process which is more effective and efficient by the supports of adequate learning facilities for students. Besides, it is also supported by Dimyati and Mudjiono [3], learning facility should support directly and indirectly in the learning process and it should be adequate and by standards in school in general.

The factors that influence student learning outcomes can also prove this study. Among the influencing factors are the level of teacher education, contextual learning methods, upgrading programs, a conducive climate, facilities and infrastructure, physical and mental conditions of teachers, work-learning motivation, managerial abilities of school principals, and others.

Cooperation from teachers is also one of the factors that can affect student learning outcomes themselves. Teachers must build communication between fellow teachers so that the implementation of assignments at school can run well because there is a relationship created from this collaboration. Cooperation between teachers and students also needs to exist to exchange information between teachers and parents. The exchange of information about the situation of students in contextual, family, and community learning approaches is something that the teacher needs to pay attention to supervise student learning activities.

As a component in the learning system, teachers play a crucial role in determining the direction and goals of a learning process. Therefore, a teacher is required to master several abilities and skills related to the learning process from planning, implementing, and evaluating.

Contextual learning methods affect student learning outcomes because, in supervisory activities, a series of activities assist teachers in developing their abilities. The principal is in charge of providing guidance, assistance, and supervision on issues related to learning development in the form of program improvements and teaching and learning activities. Supervision targets aim to teach and learn situations that allow optimal education goals to occur. This work condition is affected by learning motivation, namely the way the principal implements leadership in his school as has been done in this study.

2) The effect of contextual learning methods on the student's learning outcomes: The results showed that there was a positive effect of contextual learning methods on the sociology learning outcomes of Grade X SMA Negeri 2 Ambon. It indicated that the significance of the F-value coefficient of $651.642>$ of the F-table 2.947 at the significance level of 0.00 . The simple linear line equation took place between the variable of the contextual learning method (X1), and $\mathrm{Y}$ is $\breve{\mathrm{y}}=16.866+0.503 \mathrm{X}$. The statistical results show that the contextual learning method can make a significant contribution to student learning outcomes of $80.8 \%$. It means that the better the contextual learning method, the higher the student learning outcomes.

Contextual teaching and learning has been examined and practiced by many researchers resulting positive and significant outcome. The present study confirms Surdin [8] arguing that there is an increase in student's learning outcomes for approximately $78 \%$ by using Contextual Teaching and Learning (CTL) models on the students' learning outcomes of social science. Furthermore, for physics high school students, the study prove that by using a contextual learning approach, there is an increase in student learning outcomes [9]. Finally, Hamdayama [2] encouraged students to make connections between their knowledge and their application in everyday life which is based on their teacher's presentation about the real world brought into the classroom.

3) The effect of facilities on student's learning outcomes: The effect of the facility on the student's learning outcome indicated by the significance of the F-value coefficient of $651.642>$ of the F-table 2.947 at the significance level of 0.00 . The simple linear line equation that is formed between the facility variable (X2) and student learning outcomes (Y) in 
class X SMA Negeri 2 Ambon is $\breve{\mathrm{y}}=16,866+132 \mathrm{X}$. The statistical results show that facilities can make a significant contribution to the achievement of $93.5 \%$. It means that the better facility the school has, the better the student's learning outcomes will be.

The present study concerning facility which contributed learners' outcome is confirmed by Bijaya [15] the conditions of school infrastructure affect student learning outcomes. It means that students' achievement in learning is directly affected by the status of school infrastructure facilities. Therefore, a lack of learning facilities in schools has an impact on decreasing student learning outcomes [16]. The lack of facilities or infrastructure resulted in a lack of students' motivation in which finally leads to a lack of achievement of student learning outcomes [14]. In short, facility plays crucial role in making learners successful in their teaching-learning process.

4) The effect of motivation on student's learning outcomes: The effect of the motivation on the student's learning outcome indicated by the significance of the F-value coefficient of $651.642>$ from the F-table of 2.947 at a significance level of 0.00 . The simple linear line equation that is formed between the variable learning motivation (X3) and student learning outcomes (Y) is $\breve{\mathrm{Y}}=16,866+308 \mathrm{X}$. The statistical results indicate that learning motivation can make a significant contribution to student learning outcomes with a contribution of $93.5 \%$. This means that the higher the motivation to learn, the higher the student learning outcomes.

This study confirm Sholeh and Sa'diah [5] by arguing that students who have high motivation and adequate facilities have an impact on high learning outcomes. However, motivation not only come from the inside individual but from outside as well and therefore learning both from within and from outside individual students through appropriate and learning methods made students interested and like the teacher's learning [6]. Besides, facilities are variables that affect much the level of thinking skills and academic potential of students. It encourages increasing learning motivation and influencing student learning outcomes [12]. Also, the learning motivation has a positive influence and significant impact on the achievement of better student learning outcomes as well [13]. In short, the higher the motivation and the better the facilities make student learning outcomes increase [7].

\section{CONCLUSION}

It was concluded that there was a significant effect among contextual learning methods, facilities and learning motivation on the sociology learning outcomes of Grade X SMA Negeri 2 Ambon. In other words, contextual learning methods, facilities and learning motivation can simultaneously influence student learning outcomes. Partially, first, there is a significant influence in the use of contextual learning methods on student sociology learning outcomes. In this case, contextual learning methods can make a significant contribution to learning achievement. This means that the better the contextual learning method, the higher the student learning outcomes. Second, there is a significant effect of facilities on student sociology learning outcomes because facilities can make a significant contribution to student achievement. This means that the higher the student's learning facility, the higher the learning outcomes. Third, it is also concluded that there is a significant effect of learning motivation on student sociology learning outcomes because learning motivation can make a significant contribution to student learning outcomes. That is, the higher the student's learning motivation, the higher the learning outcomes too. Therefore, some important decision makers such as headmasters, teachers, and syllabus designers are required to pay attention to these three variables: contextual method, facility, and motivation to make teaching learning process successful

\section{ACKNOWLEDGMENT}

The authors thank Pascasarjana Universitas Kanjuruhan Malang which supports this article publication without which it is not in the present today.

\section{REFERENCES}

[1] K.T. Aritonang, "Minat dan Motivasi dalam Meningkatkan Hasil Belajar Siswa," J. Pendidik. Penabur, vol. 10, no. 7, pp. 11-21, 2008.

[2] J. Hamdayama, Model Dan Metode Pembelajaran Kreatif Dan Berkarakter. Bogor: Ghalia Indonesia, 2014.

[3] Dimyati and Mudjiono, Belajar dan Pembelajaran. Jakarta: Rineka Cipta, 2013.

[4] Mardianto, Psikologi Pendidikan. Medan: Perdana Publishing, 2012.

[5] B. Sholeh and H. Sa'diah, "Pengaruh Motivasi Belajar Dan Fasilitas Belajar Terhadap Prestasi Belajar Ips Siswa Smp Nurul Iman Parung Bogor Tahun Ajaran 2017/2018," Pekobis J. Pendidikan, Ekon. dan Bisnis, vol. 3, no. 2, p. 12, 2018

[6] R. Bakar, "International Journal of Asian Social Science The Effect of Learning Motivation on Student's Productive Competenciesin Covational High School, West Sumatera,” Int. J. Asian Sci., vol. 4, no. 6, pp. 722-732, 2014

[7] E. Riyani and Palupiningdyah, "Pengaruh Motivasi Dan Fasilitas Belajar Terhadap Hasil Belajar Siswa Mata Pelajaran Ips Ekonomi Kelas Viii Smp Negeri 1 Karangreja Purbalingga,” Econ. Educ. Anal. J., vol. 4, no. 3, pp. 887-899, 2015.

[8] Surdin, "The Effect of Contextual Teaching and Learning (CTL) Models on Learning Outcomes of Social Sciences of the Material of Forms the Face of the Earth on Class VII of Junior High School," Int. J. Educ. Res., vol. 6, no. 3, pp. 57-64, 2018.

[9] C.C.A. Neftyan, E. Suyanto, and A. Suyatna, "The Influence of Learning using Contextual Teaching and Learning Approach to Physics Learning outcomes of High School Students," Int. J. Adv. Eng. Manag. Sci., vol. 4, no. 6, pp. 446-450, 2018.

[10] Z. Taurina, "Students Motivation and Learning Outcomes: Significant Factors in Internal Study Quality Assurance Aystem," Int. J. CrossDisciplinary Subj. Educ., vol. 5, no. 4, pp. 2625-2630, 2015.

[11] M.K.O. Lee, C.M.K. Cheung, and Z. Chen, "Acceptance of Internetbased learning medium: The role of extrinsic and intrinsic motivation," Inf. Manag., vol. 42, no. 8, pp. 1095-1104, 2005.

[12] I. Jeffrey and A. Zein, "The Effects of Achievement Motivation, Learning Discipline and Learning Facilities on Student Learning Outcomes,” Int. J. Dev. Res., vol. 07, no. 09, pp. 15471-15478, 2017.

[13] N. Asvio, Arpinus, and Suharmon, "The Influence of Learning Motivation and Learning Environment on Undergraduate Students' Learning Achievement of Management of Islamic Education" Noble Int J. Sci. Res., vol. 2, no. 2, pp. 16-31, 2017. 
[14] O. Ilomo and B. Mlavi, "The availability of teaching and learning facilities and their effects on academic performance in ward secondary schools in Muheza - Tanzania," Int. J. Educ. Res., vol. 4, no. 6, pp. 571$582,2016$.

[15] N. Bijaya, "Relationship Among School' S Infrastructure Facilities, Learning Environment and Student' S Outcome," Int. J. Res. Soc. Sci. Humanit. Res., vol. 2, no. 5, pp. 44-57, 2016.
[16] M.R. Limon, "The Effect of the Adequacy of School Facilities on Studentsâ $\square$ TM Performance and Achievement in Technology and Livelihood Education," Int. J. Acad. Res. Progress. Educ. Dev., vol. 5, no. 1 , pp. 45-58, 2016. 